\title{
Pengembangan Soal Matematika Bermuatan HOTS Setara PISA Berkonteks Pancasila
}

\author{
Anifaruzki Amalia, Rusdi, Kamid \\ 1, 2, 3 Program Studi Pendidikan Matematika, Universitas Jambi, \\ Jl. Raden Mataher No.16-Jambi, Kota Jambi, Indonesia \\ anifaruzki@gmail.com
}

\begin{abstract}
In order to master mathematical literacy, it needs to be balanced with developing higher-order thinking skills, getting students used to working on high-level non-routine questions like PISA. Solving math problems using context is also a way that can be done to help students use math skills in everyday life. Mathematics is involved in helping undestand, interpret, and practice the values contained in the pancasila context. Emphasis on the value of pancasila in student's daily lives needs to be given as an alternative to developing pancasila cultural and ethical values in the world of education. This study aims to produce a set of valid and practical HOTS PISA-like in Pancasila context and have potential effects. Valid in terms of content, construct, and language based on the validator's assessment, practical based on small group, and has a potential effect based on the analysis of student answers in the field test. The researchers use design research using the of development study to reach the objective of this study. The subject of this research were 30 of 12th-grade students in SMA N 12 Jambi, Indonesia. The data were collected by walktrough, interview, test, and documentation. Based on the result of this research, it can be concluded that there are 5 unit HOTS PISA-like in Pancasila context mathematic's problems and have a potential effect on student's mathematical literacy skills where the dominant student's ability of mathematical literacy was communication ability.
\end{abstract}

Keywords: HOTS, PISA, Pancasila Context, Mathematical Literacy

\begin{abstract}
Abstrak
Dalam upaya penguasaan literasi matematis, perlu diimbangi dengan menumbuhkembangkan kemampuan berpikir tingkat tinggi yaitu membiasakan siswa mengerjakan soal non rutin berlevel tinggi setara PISA. Menyelesaikan soal matematika menggunakan konteks juga merupakan suatu cara yang dapat dilakukan untuk membantu siswa menggunakan kemampuan matematika dalam kehidupan sehari-hari. Matematika memiliki keterlibatan dalam membantu pemahaman, pemaknaan, serta pengamalan nilai-nilai yang terkandung dalam konteks pancasila. Penekanan nilai pancasila dalam kehidupan sehari-hari siswa perlu diberikan sebagai alternatif untuk mengembangkan nilai budaya dan etika pancasila di dalam dunia pendidikan. Tujuan dari penelitian ini untuk menghasilkan soal matematika bermuatan HOTS setara PISA berkonteks pancasila yang valid dan praktis, serta memiliki efek potensial. Valid dari segi konten, konstruk, dan bahasa berdasarkan penilaian validator, praktis berdasarkan uji coba small group, dan memiliki efek potensial berdasarkan analisis hasil jawaban siswa pada field test. Penelitian ini dikembangkan dengan metode design research tipe development study. Subjek penelitian ini adalah 30 orang siswa kelas XII SMA N 12 Kota Jambi. Teknik pengumpulan data dilakukan dengan walktrough, wawancara, tes, dan dokumentasi. Dari hasil penelitian dapat disimpulkan bahwa terdapat 5 unit soal matematika bermuatan HOTS setara PISA berkonteks pancasila serta mempunyai efek potensial terhadap kemampuan literasi matematika siswa dimana kemampuan yang dominan muncul yaitu kemampuan komunikasi.
\end{abstract}

Kata kunci: HOTS, PISA, Konteks Pancasila, Literasi Matematika

Copyright (c) 2021 Anifaruzki Amalia, Rusdi, Kamid

$\square$ Corresponding author: Anifaruzki Amalia

Email Address: anifaruzki@gmail.com (Jl. Raden Mathhaher, No. 16 Jambi)

Received 23 November 2020, Accepted 05 Januari 2021, Published 05 Januari 2021

\section{PENDAHULUAN}

Kurikulum 2013 merupakan hasil dari penyempurnaan kurikulum sebelumnya. Salah satu penyempurnaannya terletak pada standar penilaian dengan mengadaptasi secara bertahap modelmodel penilaian standar internasional. Penyempurnaan pada standar penilaian diharapkan dapat 
membantu siswa untuk meningkatkan kemampuan berpikir tingkat tinggi (Higher Order Thinking Skills)(Kemendikbud, 2017).

Salah satu upaya untuk meningkatkan kemampuan berpikir tingkat tinggi (Higher Order Thinking Skills) didasari oleh hasil evaluasi PISA (Program for International Student Assesment)(Kurniati et al., 2016). PISA adalah sebuah program yang dirancang oleh OECD (Organisation for Economic Co-Operation and Development) secara periodik 3 tahun sekali untuk melakukan penilaian secara internasional siswa terhadap literasi matematika. Dari hasil survei PISA Indonesia menunjukkan hasil yang selalu berada di bawah skor rata-rata internasional (OECD, 2019). Menurut (Wardani \& Rumiati, 2011) bahwa banyak kelemahan kemampuan matematika siswa Indonesia terungkap pada hasil studi PISA. Selanjutnya, (Stacey \& Turner, 2015) mengkaji tingkat literasi yang telah dicapai oleh siswa Indonesia dari tahun 2000 sampai tahun 2009, tingkat pencapaian kemampuan literasi siswa indonesia jika ditinjau dari skor yang dicapai hanya bisa mencapai nilai di bawah 400 dengan rata-rata kemampuan kognitif paling tinggi hanya bisa mencapai level 3 dan 4. Menurut Idhom (2020), selama ini soal-soal di Indonesia memiliki tingkat kesulitan di bawah PISA. Sejalan dengan pendapat (Jurnaidi \& Zulkardi, 2014), rendahnya hasil PISA disebabkan karena adanya perbedaan antara kecakapan matematika yang diajarkan di sekolah dengan yang diharapkan melalui soal PISA.

Menyikapi hasil survei tersebut, Menteri Pendidikan dan Kebudayaan, Nadiem Makarim dalam sambutannya pada puncak peringatan HUT ke-74 PGRI pada hari Sabtu, 30 November 2019, mengaku telah menyiapkan lima strategi pembelajaran holistik guna mengembangkan sumber daya manusia sekaligus meningkatkan skor PISA siswa Indonesia. Salah satu strategi yang diterapkan adalah menerapkan standar penilaian global, yaitu asesmen kompetensi minimum (AKM) yang akan digunakan untuk mengukur kinerja sekolah berdasarkan literasi dan numerasi siswa (Idhom, 2020).

Dalam upaya penguasaan literasi dan numerasi, perlu diimbangi dengan menumbuhkembangkan kemampuan berpikir tingkat tinggi dalam pemecahan masalah, kreativitas, komunikasi, dan kolaborasi (Kemendikbud et al., 2018). Untuk itu, salah satu upaya yang bisa dilakukan oleh guru adalah dengan membiasakan siswa untuk mengerjakan soal non rutin yang mengandung konteks berlevel tinggi setara PISA untuk melatih anak-anak berpikir kritis, kreatif dan analitis serta mengasah literasi siswa. Sehingga, diperlukan soal-soal pengembangan PISA yang diberikan dalam pembelajaran sebagai alternatif bagi siswa untuk berlatih dan tidak merasa asing lagi dengan soal-soal non-rutin bermuatan HOTS setara soal PISA.

Selain menggunakan soal matematika bermuatan HOTS setara PISA dalam pembelajaran, penggunaan konteks juga dinilai sangat penting. Dalam matematika, penggunaan konteks memiliki beberapa manfaat, diantaranya adalah berguna untuk pembentukan konsep, pembentukan model, akses dan motivasi terhadap matematika, alat untuk berpikir menggunakan prosedur, notasi, gambar dan aturan, realitas sebagai sumber dan domain aplikasi, dan latihan kemampuan spesifik di situasisituasi tertentu (Heuvel-Panhuizen, 1996; Wahyudi, 2016). Pada penelitian ini, konteks yang 
dihadirkan adalah konteks Pancasila. Konteks ini dipilih karena sejak awal duduk di bangku sekolah, sebagian besar siswa sudah mendapatkan materi mengenai pendidikan pancasila. Namun, terdapat minimnya pemahaman pancasila di dalam kehidupan bermasyarakat. Sejalan dengan yang dikatakan oleh (Sutopo, 2020), sejak era reformasi, di dalam dunia pendidikan, pancasila semakin jarang digunakan sebagai inspirasi pembentukan karakter siswa, kurang dimanfaatkan sebagai dasar pengembangan kurikulum dan pembelajaran, serta tidak digunakan sebagai pedoman perilaku pelajar. Akibatnya, nilai budaya dan etika pancasila tidak berkembang di lembaga pendidikan, bahkan menghilang.

Lebih lanjut, (Panjaitan, 2020) mengatakan bahwa proses globalisasi memungkinkan terjadinya pertukaran informasi, teknologi, ilmu pengetahuan, dan budaya. Pertukaran di berbagai bidang akan memberikan dampak positif dan negatif. Dampak negatif dari pertukaran budaya adalah masuknya nilai-nilai budaya luar yang tidak sejalan dengan nilai-nilai luhur identitas nasional indonesia. Apabila kebudayaan tersebut tidak sesuai dengan kebudayaan indonesia, maka proses globalisasi secara langsung mengakibatkan turunnya akhlak bangsa bagi generasi muda yang menjadi aset bangsa di masa depan. Dengan demikian, wadah untuk menerapkan nilai pancasila melalui sistem dan cara yang kekinian sangat diperlukan. Sejalan dengan yang dikatakan (Dewi, 2020), dampak globalisasi dan demokrasi tidak bisa dibentung. Hal yang perlu dilakukan adalah mengembangkan strategi agar budaya di berbagai belahan dunia tidak memecah dan menghilangkan budaya lokal.

Matematika memiliki keterlibatan dalam membantu pemahaman, pemaknaan, serta pengamalan nilai-nilai yang terkandung dalam pancasila (JULAIKA \& MARIANA, 2018). Berdasarkan karakteristik tersebut, fokus penelitian ini pada nilai praksis pancasila yaitu aktualisasi nilai-nilai pancasila yang ada di dalam kehidupan sehari-hari siswa yang dilihat berdasarkan butirbutir pancasila yang ditetapkan dalam Ketetapan MPR No. II/MPR/1978 tentang Ekaprasetya Pancakarsa dan merupakan perwujudan dari nilai dasar Pancasila, yaitu nilai ketuhanan, kemanusiaan, persatuan, kerakyatan, dan keadilan.

Penekanan nilai pancasila dalam keseharian siswa perlu diberikan, termasuk dalam pembelajaran matematika (Widiatsih, 2020). Dalam ruang lingkup pancasila, terdapat berbagai hal yang memuat konsep-konsep matematika termasuk konten matematika dalam PISA. Berdasarkan framework PISA matematika 2018, konten matematika dalam PISA salah satunya terdiri dari ketidakpastian dan data (OECD, 2019). Bermacam-macam konten yang lebih spesifik di dalamnya, seperti pada ukuran pemusatan data, ukuran penyebaran data, dan sebagainya terdapat dalam konteks Pancasila. Hal ini dapat ditemukan pada nilai-nilai praksis pancasila seperti nilai ketuhanan, kemanusiaan, persatuan, kerakyatan, dan keadilan. Untuk implementasi nilai kemanusiaan (sila kedua) yang sesuai dengan Ketetapan MPR No.II/MPR/1978 misalnya, butir-butir pancasila yang harus ditanamkan dalam keseharian siswa yaitu saling mencintai sesama, mengembangkan sikap tenggang rasa, menunjunjung tinggi nilai kemanusiaan. Untuk itu, konteks pancasila dalam pembuatan soal matematika bermuatan HOTS setara PISA memiliki potensi untuk diterapkan dan 
dapat dijadikan sumber referensi dalam pembelajaran matematika di sekolah. Berdasarkan uraian tersebut, maka peneliti tertarik untuk mengadakan penelitian dengan judul "Pengembangan soal matematika bermuatan HOTS setara PISA berkonteks Pancasila".

\section{METODE}

Metode dalam penelitian ini adalah metode penelitian design research dengan tipe development study atau penelitian pengembangan. Penelitian pengembangan ini adalah jenis penelitian yang ditunjukan untuk menghasilkan soal matematika bermuatan HOTS setara PISA di kelas XII SMA yang valid dan praktis serta memiliki efek potensial. Tahap-tahap yang dilakukan peneliti adalah tahap preliminary dan tahap prototyping (formative evaluation) yang meliputi self evaluation, expert reviews, dan oneto-one, small group, dan field test. (Tessmer, 1993).

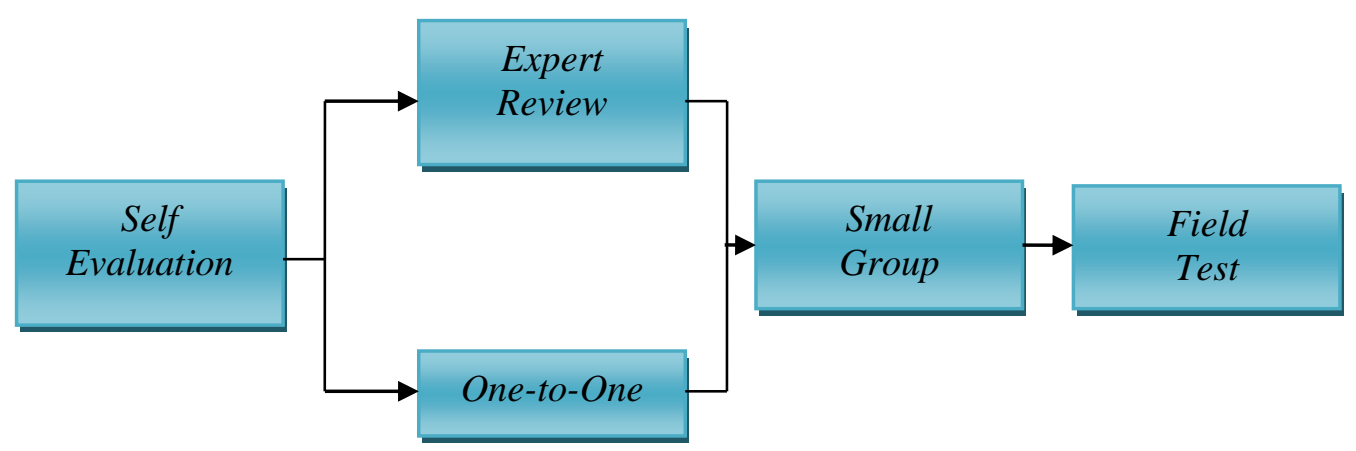

Gambar 1. Alur Desain Formative Evaluation

Subjek penelitian ini adalah siswa kelas XII SMA N 12 Kota Jambi, diadakan pada semester ganjil tahun ajaran 2020/2021. Teknik pengumpulan data yang digunakan adalah: a) Dokumentasi, b) Walk-through, c) tes, d) wawancara. Teknik analisis data yang digunakan dalam penelitian ini berdasarkan tahapan-tahapan sebagai berikut:

\section{Analisis Data Validasi Ahli}

Untuk menganalisis data validasi ahli digunakan analisis deskriptif dengan cara merevisi berdasarkan catatan validator. Hasil dari analisis digunakan untuk merevisi soal-soal yang dibuat oleh peneliti. Hasil dari analisis ini akan digunakan untuk merevisi soal-soal matematika bermuatan HOTS setara PISA berkonteks pancasila yang telah dibuat peneliti yang berfokus pada tiga karakteristik, yaitu konten, konstruk, dan bahasa.

Tabel 1. Karakteristik yang menjadi Fokus Prototype

\begin{tabular}{|c|l|}
\hline Karakteristik & \multicolumn{1}{c|}{ Keterangan } \\
\hline Konten & $\bullet \begin{array}{l}\text { Soal sesuai dengan indikator kemampuan berpikir tingkat tinggi } \\
\text { dan level PISA }\end{array}$ \\
& $\begin{array}{l}\text { Soal sesuai dengan indikator kemampuan literasi matematis } \\
\text { - Soal sesuai dengan kompetensi dasar pada kurikulum dan materi } \\
\text { yang diujikan }\end{array}$ \\
\hline Konstruk & $\begin{array}{l}\text { Soal sesuai dengan teori dan kriteria: } \\
\text { Batasan/ruang lingkup soal dan jawaban yang diharapkan jelas } \\
\end{array}$ \\
& Sesuai dengan kompetensi (urgensi, relevansi, kontinuitas, dan \\
\hline
\end{tabular}




\begin{tabular}{|c|c|}
\hline & $\begin{array}{ll} & \text { keterpakaian sehari-hari) } \\
\text { - } & \text { Soal memuat nilai praksis pancasila } \\
\text { - Tabel, grafik, gambar disajikan dengan jelas, terbaca, dan } \\
\text { berfungsi } \\
\text { - } \quad \text { Terdapat petunjuk/informasi yang cukup untuk mengerjakan soal } \\
\text { - Sesuai dengan framework PISA } 2018\end{array}$ \\
\hline Bahasa & $\begin{array}{ll} & \text { Sesuai dengan EBI (Ejaan Bahasa Indonesia) } \\
\text { - } & \text { Soal tidak berbelit-belit } \\
\text { - } & \text { Soal tidak mengandung penafsiran ganda }\end{array}$ \\
\hline
\end{tabular}

\section{Analisis Data Kepraktisan Soal}

Untuk menganalisis data kepraktisan soal-soal bermuatan HOTS setara PISA berkonteks Pancasila digunakan analisis deskriptif yang diperoleh selama siswa mengerjakan soal-soal bermuatan HOTS setara PISA berkonteks Pancasila. Hasil dari analisis digunakan untuk merevisi soal-soal yang dibuat oleh peneliti.

\section{Analisis Data Tes Soal-soal bermuatan HOTS setara PISA berkonteks Pancasila}

Untuk melihat kemampuan literasi matematis siswa dapat diketahui berdasarkan hasil tes soal-soal yang dikembangkan. Selanjutnya, uji coba dilakukan pada subjek penelitian yang sesungguhnya sebagai field test. Produk yang telah diujicobakan pada field test haruslah yang telah memenuhi kriteria kualitas. (Van den Akker, 1999) mengemukakan bahwa tiga kriteria kualitas adalah: validitas (dari pakar, teman sejawat, dan guru matematika), kepraktisan (penggunaannya mudah dan dapat digunakan dalam proses pembelajaran), dan soal memiliki efek potensial dilihat dari hasil tes kemampuan literasi matematis siswa menggunakan indikator dari tujuh kemampuan literasi matematis berdasarkan famework PISA yang muncul seperti di bawah ini (OECD, 2019).

Tabel 2. Indikator Kemampuan Matematika pada Framework PISA (Proses Formulate)

\begin{tabular}{|l|l|}
\hline \multicolumn{2}{|c|}{ Kemampuan Komunikasi } \\
\hline \multicolumn{1}{|c|}{ Indikator yang dinilai } \\
$\begin{array}{l}\text { Menerjemahkan pernyataan, } \\
\text { pertanyaan, soal, objek dan } \\
\text { gambar }\end{array}$ & $\begin{array}{l}\text { Tidak dapat menerjemahkan pernyataan, pertanyaan, soal, objek, dan } \\
\text { gambar }\end{array}$ \\
\cline { 2 - 3 } & $\begin{array}{l}\text { Dapat menerjemahkan pernyataan, pertanyaan, soal, objek, dan } \\
\text { gambar, tetapi masih belum lengkap }\end{array}$ \\
\cline { 2 - 3 } & $\begin{array}{l}\text { Dapat menerjemahkan pernyataan, pertanyaan, soal, objek, dan } \\
\text { gambar dengan lengkap dan benar }\end{array}$ \\
\hline 2. Kemampuan Matematisasi \\
\hline Indikator yang dinilai \\
\multirow{2}{*}{$\begin{array}{l}\text { Mengidentifikasi variabel } \\
\text { dan struktur matematika } \\
\text { yang mendasar dalam } \\
\text { masalah dunia nyata }\end{array}$} & $\begin{array}{l}\text { Tidak dapat mengidentifikasi variabel dan struktur matematika yang } \\
\text { mendasar dalam masalah dunia nyata }\end{array}$ \\
\cline { 2 - 3 } & $\begin{array}{l}\text { Dapat mengidentifikasi variabel dan struktur matematika yang } \\
\text { mendasar dalam masalah dunia nyata, tetapi masih belum lengkap }\end{array}$ \\
\cline { 2 - 3 } & $\begin{array}{l}\text { Dapat Mengidentifikasi variabel dan struktur matematika yang } \\
\text { mendasar dalam masalah dunia nyata dengan lengkap dan benar }\end{array}$ \\
\hline \multirow{2}{*}{$\begin{array}{l}\text { Membuat asumsi } \\
\text { matematika }\end{array}$} & Tidak dapat membuat asumsi matematika \\
\cline { 2 - 3 } & Dapat membuat asumsi matematika, tetapi masih belum lengkap \\
\hline
\end{tabular}




\begin{tabular}{|c|c|}
\hline & Dapat membuat asumsi matematika dengan lengkap dan benar \\
\hline \multicolumn{2}{|l|}{ 3. Kemampuan Representasi } \\
\hline Indikator yang dinilai & Respon terhadap Soal \\
\hline \multirow{3}{*}{$\begin{array}{l}\text { Membuat representasi } \\
\text { matematika dari informasi } \\
\text { dunia nyata }\end{array}$} & $\begin{array}{l}\text { Tidak dapat membuat representasi matematika dari informasi dunia } \\
\text { nyata }\end{array}$ \\
\hline & $\begin{array}{l}\text { Dapat membuat representasi matematika dari informasi dunia nyata, } \\
\text { tetapi masih belum lengkap }\end{array}$ \\
\hline & $\begin{array}{l}\text { Dapat membuat representasi matematika dari informasi dunia nyata } \\
\text { dengan lengkap dan benar }\end{array}$ \\
\hline \multicolumn{2}{|c|}{ 4. Kemampuan Penalaran dan Argumen } \\
\hline Indikator yang dinilai & Respon terhadap Soal \\
\hline \multirow{3}{*}{\begin{tabular}{lr}
\multicolumn{2}{l}{ Menjelaskan pembenaran } \\
untuk representasi situasi \\
dunia nyata & yang \\
teridentifikasi & atau \\
dirancang &
\end{tabular}} & $\begin{array}{l}\text { Tidak dapat menjelaskan pembenaran untuk representasi situasi } \\
\text { dunia nyata yang teridentifikasi atau dirancang }\end{array}$ \\
\hline & $\begin{array}{l}\text { Dapat menjelaskan pembenaran untuk representasi situasi dunia } \\
\text { nyata yang teridentifikasi atau dirancang, tetapi masih belum lengkap }\end{array}$ \\
\hline & $\begin{array}{l}\text { Dapat menjelaskan pembenaran untuk representasi situasi dunia } \\
\text { nyata yang teridentifikasi atau dirancang dengan lengkap dan benar }\end{array}$ \\
\hline \multicolumn{2}{|c|}{ 5. Kemampuan Memilih Strategi untuk Memecahkan Masalah } \\
\hline Indikator yang dinilai & Respon terhac \\
\hline \multirow{3}{*}{$\begin{array}{lr}\text { Menentukan } & \text { strategi } \\
\text { membentuk untuk } \\
\text { kontekstual }\end{array}$} & $\begin{array}{l}\text { Tidak dapat menentukan strategi untuk membentuk ulang masalah } \\
\text { kontekstual secara matematis }\end{array}$ \\
\hline & $\begin{array}{l}\text { Dapat menentukan strategi untuk membentuk ulang masalah } \\
\text { kontekstual secara matematis, tetapi masih belum lengkap }\end{array}$ \\
\hline & $\begin{array}{l}\text { Dapat menentukan strategi untuk membentuk ulang masalah } \\
\text { kontekstual secara matematis dengan lengkap dan benar }\end{array}$ \\
\hline \multicolumn{2}{|c|}{ 6. Kemampuan menggunakan Bahasa dan Operasi Simbolis, Formal, dan Teknis } \\
\hline Indikator yang dinilai & Respon terhadap Soal \\
\hline \multirow{3}{*}{\begin{tabular}{lr} 
Menggunakan variabel, & vanbol, diagram, dan model \\
simar & standar yang sesuai untuk \\
merepresentasikan & masalah \\
dunia nyata dengan & menggunakan bahasa \\
\multicolumn{2}{l}{ simbolis atau formal }
\end{tabular}} & $\begin{array}{l}\text { Tidak dapat menggunakan variabel, simbol, diagram, dan model } \\
\text { standar yang sesuai untuk merepresentasikan masalah dunia nyata } \\
\text { dengan menggunakan bahasa simbolis atau formal }\end{array}$ \\
\hline & $\begin{array}{l}\text { Dapat menggunakan variabel, simbol, diagram, dan model standar } \\
\text { yang sesuai untuk merepresentasikan masalah dunia nyata dengan } \\
\text { menggunakan bahasa simbolis atau formal, tetapi masih belum } \\
\text { lengkap }\end{array}$ \\
\hline & $\begin{array}{l}\text { Dapat menggunakan variabel, simbol, diagram, dan model standar } \\
\text { yang sesuai untuk merepresentasikan masalah dunia nyata dengan } \\
\text { menggunakan bahasa simbolis atau formal dengan lengkap dan benar }\end{array}$ \\
\hline \multicolumn{2}{|c|}{ 7. Kemampuan Menggunakan Alat-alat Matematika } \\
\hline Indikator yang dinilai & Respon terhadap Soal \\
\hline \multirow{3}{*}{$\begin{array}{lr}\text { Menggunakan } & \text { alat-alat } \\
\text { matematika } & \text { untuk } \\
\text { mengenali } & \text { struktur } \\
\text { matematika atau untuk } \\
\text { menggambarkan hubungan } \\
\text { matematis }\end{array}$} & $\begin{array}{l}\text { Tidak dapat menggunakan alat-alat matematika untuk mengenali } \\
\text { struktur matematika atau untuk menggambarkan hubungan } \\
\text { matematis }\end{array}$ \\
\hline & $\begin{array}{l}\text { Dapat menggunakan alat-alat matematika untuk mengenali struktur } \\
\text { matematika atau untuk menggambarkan hubungan matematis, tetapi } \\
\text { masih belum lengkap }\end{array}$ \\
\hline & Dapat menggunakan alat-alat matematika untuk mengenali struktur \\
\hline
\end{tabular}


matematika atau untuk menggambarkan hubungan matematis dengan

lengkap dan benar

Tabel 3. Indikator Kemampuan Matematika pada Framework PISA (Proses Employe)

\begin{tabular}{|c|c|}
\hline \multicolumn{2}{|l|}{ 1. Kemampuan Komunikasi } \\
\hline Indikator yang dinilai & Respon terhadap Soal \\
\hline \multirow{3}{*}{$\begin{array}{l}\text { Menuliskan proses dalam } \\
\text { mencapai solusi }\end{array}$} & Tidak dapat menuliskan proses dalam mencapai solusi \\
\hline & $\begin{array}{l}\text { Dapat menuliskan proses dalam mencapai solusi, tetapi masih } \\
\text { belum lengkap }\end{array}$ \\
\hline & $\begin{array}{l}\text { Dapat menuliskan proses dalam mencapai solusi dengan lengkap } \\
\text { dan benar }\end{array}$ \\
\hline \multirow{3}{*}{$\begin{array}{l}\text { Menyimpulkan hasil } \\
\text { matematika }\end{array}$} & Tidak menuliskan proses dalam mencapai solusi \\
\hline & $\begin{array}{l}\text { Dapat menuliskan proses dalam mencapai solusi, tetapi masih } \\
\text { belum lengkap }\end{array}$ \\
\hline & $\begin{array}{l}\text { Dapat menuliskan proses dalam mencapai solusi dengan lengkap } \\
\text { dan benar }\end{array}$ \\
\hline \multicolumn{2}{|c|}{ 2. Kemampuan Matematisasi } \\
\hline Indikator yang dinilai & Respon terhadap Soal \\
\hline \multirow{3}{*}{$\begin{array}{l}\text { Menggunakan pemahaman } \\
\text { konteks untuk } \\
\text { menyelesaikan masalah } \\
\text { matematika }\end{array}$} & $\begin{array}{l}\text { Tidak dapat menggunakan pemahaman konteks untuk } \\
\text { menvelesaikan masalah matematika }\end{array}$ \\
\hline & $\begin{array}{l}\text { Dapat menggunakan pemahaman konteks untuk menyelesaikan } \\
\text { masalah matematika, tetapi masih belum lengkap }\end{array}$ \\
\hline & $\begin{array}{l}\text { Dapat menggunakan pemahaman konteks untuk menyelesaikan } \\
\text { masalah matematika dengan lengkap dan benar }\end{array}$ \\
\hline \multicolumn{2}{|c|}{ 3. Kemampuan Matematisasi } \\
\hline Indikator yang dinilai & Respon terhadap Soal \\
\hline \multirow{3}{*}{$\begin{array}{l}\text { Menghubungkan berbagai } \\
\text { macam representasi saat } \\
\text { menyelesaikan masalah }\end{array}$} & $\begin{array}{l}\text { Tidak dapat menghubungkan berbagai macam representasi saat } \\
\text { menyelesaikan masalah }\end{array}$ \\
\hline & $\begin{array}{l}\text { Dapat menghubungkan berbagai macam representasi saat } \\
\text { menyelesaikan masalah, tetapi masih belum lengkap }\end{array}$ \\
\hline & $\begin{array}{l}\text { Dapat menghubungkan berbagai macam representasi saat } \\
\text { menyelesaikan masalah dengan lengkap dan benar }\end{array}$ \\
\hline \multicolumn{2}{|c|}{ 4. Kemampuan Penalaran dan Argumen } \\
\hline Indikator yang dinilai & Respon terhadap Soal \\
\hline \multirow{3}{*}{$\begin{array}{l}\text { Menjelaskan pembenaran } \\
\text { dalam menentukan proses } \\
\text { dan prosedur yang } \\
\text { digunakan } \\
\text { menentukan hasil atau } \\
\text { solusi matematis }\end{array}$} & $\begin{array}{l}\text { Tidak dapat menjelaskan pembenaran dalam menentukan proses } \\
\text { dan prosedur yang digunakan untuk menentukan hasil atau solusi } \\
\text { matematis }\end{array}$ \\
\hline & $\begin{array}{l}\text { Dapat menjelaskan pembenaran dalam menentukan proses dan } \\
\text { prosedur yang digunakan untuk menentukan hasil atau solusi } \\
\text { matematis, tetapi masih belum lengkap }\end{array}$ \\
\hline & $\begin{array}{l}\text { Dapat menjelaskan pembenaran dalam menentukan proses dan } \\
\text { prosedur yang digunakan untuk menentukan hasil atau solusi } \\
\text { matematis dengan lengkap dan benar }\end{array}$ \\
\hline \multirow{2}{*}{ 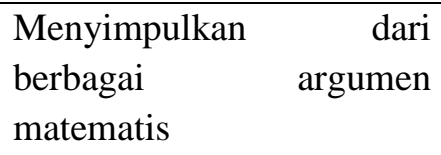 } & Tidak dapat menyimpulkan dari berbagai argumen matematis \\
\hline & $\begin{array}{l}\text { Dapat menyimpulkan dari berbagai argumen matematis, tetapi } \\
\text { masih belum lengkap }\end{array}$ \\
\hline
\end{tabular}




\begin{tabular}{|c|c|}
\hline & $\begin{array}{l}\text { Dapat menyimpulkan dari berbagai argumen matematis dengan } \\
\text { lengkap dan benar }\end{array}$ \\
\hline \multicolumn{2}{|c|}{ 5. Kemampuan Memilih Strategi untuk Memecahkan Masalah } \\
\hline Indikator yang dinilai & Respon terhadap Soal \\
\hline \multirow{3}{*}{$\begin{array}{lr}\text { Menggunakan } & \text { strategi } \\
\text { melalui berbagai prosedur } \\
\text { yang mengarah kepada } \\
\text { solusi dan kesimpulan } \\
\text { matematis }\end{array}$} & $\begin{array}{l}\text { Tidak dapat menggunakan strategi melalui berbagai prosedur yang } \\
\text { mengarah kepada solusi dan kesimpulan matematis }\end{array}$ \\
\hline & $\begin{array}{l}\text { Dapat menggunakan strategi melalui berbagai prosedur yang } \\
\text { mengarah kepada solusi dan kesimpulan matematis, tetapi masih } \\
\text { belum lengkap }\end{array}$ \\
\hline & $\begin{array}{l}\text { Dapat menggunakan strategi melalui berbagai prosedur yang } \\
\text { mengarah kepada solusi dan kesimpulan matematis dengan } \\
\text { lengkap dan benar }\end{array}$ \\
\hline \multicolumn{2}{|c|}{ 6. Kemampuan menggunakan bahasa dan operasi simbolis, formal, dan teknis } \\
\hline Indikator yang dinilai & Respon terhadap Soal \\
\hline \multirow{3}{*}{ 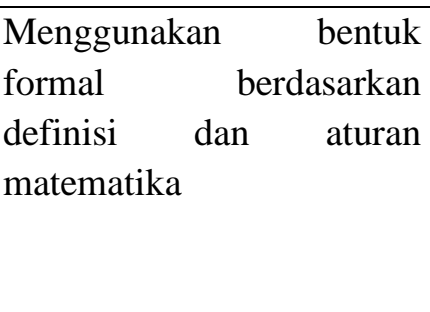 } & $\begin{array}{l}\text { Tidak dapat menggunakan bentuk formal berdasarkan definisi dan } \\
\text { aturan matematika }\end{array}$ \\
\hline & $\begin{array}{l}\text { Dapat menggunakan bentuk formal berdasarkan definisi dan } \\
\text { aturan matematika, tetapi masih belum lengkap }\end{array}$ \\
\hline & $\begin{array}{l}\text { Dapat menggunakan bentuk formal berdasarkan definisi dan } \\
\text { aturan matematika dengan lengkap dan benar }\end{array}$ \\
\hline \multicolumn{2}{|c|}{ 7. Kemampuan menggunakan alat-alat matematika } \\
\hline Indikator yang dinilai & Respon terhadap Soal \\
\hline \multirow{3}{*}{$\begin{array}{lr}\text { Menggunakan alat-alat } \\
\text { matematika } \\
\text { mengenali untuk } \\
\text { matematika atau untuk } \\
\text { menggambarkan hubungan } \\
\text { matematis }\end{array}$} & $\begin{array}{l}\text { Tidak dapat menggunakan alat-alat matematika untuk mengenali } \\
\text { struktur matematika atau untuk menggambarkan hubungan } \\
\text { matematis }\end{array}$ \\
\hline & $\begin{array}{l}\text { Dapat menggunakan alat-alat matematika untuk mengenali } \\
\text { struktur matematika atau untuk menggambarkan hubungan } \\
\text { matematis, tetapi masih belum lengkap }\end{array}$ \\
\hline & $\begin{array}{l}\text { Dapat menggunakan alat-alat matematika untuk mengenali } \\
\text { struktur matematika atau untuk menggambarkan hubungan } \\
\text { matematis dengan lengkap dan benar }\end{array}$ \\
\hline
\end{tabular}

Tabel 4. Indikator Kemampuan Matematika pada Framework PISA(Proses Interprete)

\begin{tabular}{|l|l|}
\hline \multicolumn{1}{|l|}{ 1. Kemampuan Komunikasi } \\
\hline \multicolumn{1}{|c|}{ Indikator yang dinilai } \\
$\begin{array}{l}\text { Membuat penjelasan dan } \\
\text { argumentasi dalam konteks } \\
\text { masalah }\end{array}$ & $\begin{array}{l}\text { Tidak dapat membuat penjelasan dan argumentasi dalam konteks } \\
\text { masalah }\end{array}$ \\
\cline { 2 - 2 } & $\begin{array}{l}\text { Dapat membuat penjelasan dan argumentasi dalam konteks } \\
\text { masalah, tetapi masih belum lengkap }\end{array}$ \\
\cline { 2 - 3 } & $\begin{array}{l}\text { Dapat membuat penjelasan dan argumentasi dalam konteks } \\
\text { masalah dengan lengkap dan benar }\end{array}$ \\
\hline $\begin{array}{l}\text { Mengomunikasikan } \\
\text { penjelasan dan argumentasi } \\
\text { dalam konteks masalah }\end{array}$ & $\begin{array}{l}\text { Tidak mengomunikasikan penjelasan dan argumentasi dalam } \\
\text { konteks masalah }\end{array}$ \\
\cline { 2 - 3 } & $\begin{array}{l}\text { Dapat mengomunikasikan penjelasan dan argumentasi dalam } \\
\text { konteks masalah, tetapi masih belum lengkap }\end{array}$ \\
\cline { 2 - 3 } & Dapat mengomunikasikan penjelasan dan argumentasi dalam \\
\hline
\end{tabular}




\begin{tabular}{|c|c|}
\hline & konteks masalah dengan lengkap dan benar \\
\hline \multicolumn{2}{|l|}{ 2. Kemampuan Matematisasi } \\
\hline Indikator yang dinilai & Respon terhadap Soal \\
\hline \multirow{3}{*}{$\begin{array}{l}\text { Menentukan batasan solusi } \\
\text { matematika }\end{array}$} & Tidak dapat menentukan batasan solusi matematika \\
\hline & $\begin{array}{l}\text { Dapat menentukan batasan solusi matematika, tetapi masih belum } \\
\text { lengkap }\end{array}$ \\
\hline & $\begin{array}{l}\text { Dapat menentukan batasan solusi matematika dengan lengkap dan } \\
\text { benar }\end{array}$ \\
\hline \multicolumn{2}{|l|}{ 3. Kemampuan Representasi } \\
\hline Indikator yang dinilai & Respon terhadap Soal \\
\hline \multirow{3}{*}{$\begin{array}{l}\text { Menginterpretasikan } \\
\text { matematika dalam } \\
\text { bentuk representasi }\end{array}$} & $\begin{array}{l}\text { Tidak dapat menghubungkan berbagai macam representasi saat } \\
\text { menyelesaikan masalah }\end{array}$ \\
\hline & $\begin{array}{l}\text { Dapat menghubungkan berbagai macam representasi saat } \\
\text { menyelesaikan masalah, tetapi masih belum lengkap }\end{array}$ \\
\hline & $\begin{array}{l}\text { Dapat menghubungkan berbagai macam representasi saat } \\
\text { menyelesaikan masalah dengan lengkap dan benar }\end{array}$ \\
\hline \multirow{3}{*}{$\begin{array}{l}\text { Membandingkan dua atau } \\
\text { lebih representasi yang } \\
\text { berhubungan dengan situasi }\end{array}$} & $\begin{array}{l}\text { Tidak dapat membandingkan dua atau lebih representasi yang } \\
\text { berhubungan dengan situasi }\end{array}$ \\
\hline & $\begin{array}{l}\text { Dapat membandingkan dua atau lebih representasi yang } \\
\text { berhubungan dengan situasi, tetapi masih belum lengkap }\end{array}$ \\
\hline & $\begin{array}{l}\text { Dapat membandingkan dua atau lebih representasi yang } \\
\text { berhubungan dengan situasi dengan lengkap dan benar }\end{array}$ \\
\hline \multirow{3}{*}{$\begin{array}{l}\text { Mengevaluasi dua atau } \\
\text { lebih representasi yang } \\
\text { berhubungan dengan situasi }\end{array}$} & $\begin{array}{l}\text { Tidak dapat mengevaluasi dua atau lebih representasi yang } \\
\text { berhubungan dengan situasi }\end{array}$ \\
\hline & $\begin{array}{l}\text { Dapat Mengevaluasi dua atau lebih representasi yang berhubungan } \\
\text { dengan situasi, tetapi masih belum lengkap }\end{array}$ \\
\hline & Dapat tetapi masih belum lengkap dengan lengkap dan benar \\
\hline \multicolumn{2}{|c|}{ 4. Kemampuan Penalaran dan Argumen } \\
\hline Indikator yang dinilai & Respon terhadap Soal \\
\hline \multirow{3}{*}{$\begin{array}{l}\text { Merefleksikan } \\
\text { (mengartikan) } \\
\text { matematika }\end{array}$} & Tidak dapat merefleksikan (mengartikan) solusi matematika \\
\hline & $\begin{array}{l}\text { Dapat merefleksikan (mengartikan) solusi matematika, tetapi } \\
\text { masih belum lengkap }\end{array}$ \\
\hline & $\begin{array}{l}\text { Dapat merefleksikan (mengartikan) solusi matematika dengan } \\
\text { lengkap dan benar }\end{array}$ \\
\hline \multirow{3}{*}{$\begin{array}{l}\text { Membuat penjelasan dan } \\
\text { penalaran yang mendukung, } \\
\text { menyangkal, } \\
\text { memenuhi syarat suatu } \\
\text { solusi matematika ke } \\
\text { masalah kontekstual }\end{array}$} & $\begin{array}{l}\text { Tidak dapat membuat penjelasan dan penalaran yang mendukung, } \\
\text { menyangkal, atau memenuhi syarat suatu solusi matematika ke } \\
\text { masalah kontekstual }\end{array}$ \\
\hline & $\begin{array}{l}\text { Dapat membuat penjelasan dan penalaran yang mendukung, } \\
\text { menyangkal, atau memenuhi syarat suatu solusi matematika ke } \\
\text { masalah kontekstual, tetapi masih belum lengkap }\end{array}$ \\
\hline & $\begin{array}{l}\text { Dapat membuat penjelasan dan penalaran yang mendukung, } \\
\text { menyangkal, atau memenuhi syarat suatu solusi matematika ke } \\
\text { masalah kontekstual dengan lengkap dan benar }\end{array}$ \\
\hline \multicolumn{2}{|c|}{ 5. Kemampuan memilih strategi untuk memecahkan masalah } \\
\hline Indikator yang dinilai & Respon terhadap Soal \\
\hline
\end{tabular}




\begin{tabular}{|c|c|}
\hline \multirow{3}{*}{$\begin{array}{l}\text { Menerapkan sebuah strategi } \\
\text { untuk menafsirkan, menilai, } \\
\text { dan memvalidasi solusi } \\
\text { matematika terhadap } \\
\text { masalah kontekstual }\end{array}$} & $\begin{array}{l}\text { Tidak dapat menerapkan sebuah strategi untuk menafsirkan, } \\
\text { menilai, dan memvalidasi solusi matematika terhadap masalah } \\
\text { kontekstual }\end{array}$ \\
\hline & $\begin{array}{l}\text { Dapat menerapkan sebuah strategi untuk menafsirkan, menilai, } \\
\text { dan memvalidasi solusi matematika terhadap masalah kontekstual, } \\
\text { tetapi masih belum lengkap }\end{array}$ \\
\hline & $\begin{array}{l}\text { Dapat menerapkan sebuah strategi untuk menafsirkan, menilai, } \\
\text { dan memvalidasi solusi matematika terhadap masalah kontekstual } \\
\text { dengan lengkap dan benar }\end{array}$ \\
\hline \multicolumn{2}{|c|}{ 6. Kemampuan menggunakan bahasa dan operasi simbolis, formal, dan teknis } \\
\hline Indikator yang dinilai & Respon terhadap Soal \\
\hline \multirow{3}{*}{$\begin{array}{l}\text { Membuat hubungan antara } \\
\text { konteks suatu masalah dan } \\
\text { representasi } \quad \text { solusi } \\
\text { matematika }\end{array}$} & $\begin{array}{l}\text { Tidak dapat membuat hubungan antara konteks suatu masalah dan } \\
\text { representasi solusi matematika }\end{array}$ \\
\hline & $\begin{array}{l}\text { Dapat membuat hubungan antara konteks suatu masalah dan } \\
\text { representasi solusi matematika, tetapi masih belum lengkap }\end{array}$ \\
\hline & $\begin{array}{l}\text { Dapat membuat hubungan antara konteks suatu masalah dan } \\
\text { representasi solusi matematika dengan lengkap dan benar }\end{array}$ \\
\hline \multicolumn{2}{|c|}{ 7. Kemampuan menggunakan alat-alat matematika } \\
\hline Indikator yang dinilai & Respon terhadap Soal \\
\hline \multirow{3}{*}{$\begin{array}{lr}\text { Menggunakan } & \text { alat-alat } \\
\text { matematika } & \text { untuk } \\
\text { memeriksa kembali } & \text { solusi } \\
\text { matematika } & \end{array}$} & $\begin{array}{l}\text { Tidak dapat menggunakan alat-alat matematika untuk memeriksa } \\
\text { kembali solusi matematika }\end{array}$ \\
\hline & $\begin{array}{l}\text { Dapat menggunakan alat-alat matematika untuk memeriksa } \\
\text { kembali solusi matematika, tetapi masih belum lengkap }\end{array}$ \\
\hline & $\begin{array}{l}\text { Dapat menggunakan alat-alat matematika untuk memeriksa } \\
\text { kembali solusi matematika dengan lengkap dan benar }\end{array}$ \\
\hline
\end{tabular}

\section{HASIL DAN DISKUSI}

Berdasarkan langkah-langkah pengembangan soal sebagaimana yang telah diuraikan sebelumnya, tahapan pengembangan soal terdiri dari tahap preliminary dan tahap prototyping (self evaluation, expert reviews, one-to-one-small group, serta field test).

\section{Tahap Persiapan (Preliminary)}

Pada tahap ini, peneliti melakukan persiapan dengan mengkaji atau menganalisis tentang siswa, kurikulum, materi, soal-soal PISA, dan pendesainan soal sebagaimana diuraikan sebagai berikut:

\section{Analisis}

- Analisis Siswa

Analisis siswa bertujuan untuk mengetahui kemampuan matematika siswa. Dalam memilih subjek penelitian, yaitu siswa kelas XII SMA N 12 Kota Jambi dengan kemampuan yang heterogen.

- Analisis Kurikulum

Penganalisisan kurikulum dilakukan dengan mengidentifikasi materi-materi pembelajaran yang berhubungan dengan konten-konten pada PISA berdasarkan kurikulum 2013 yang telah dirumuskan untuk siswa kelas XII SMA. Materi-materi yang dimaksud tersebar pada materi SMA pada konten uncertainty and data, yaitu: 
Tabel 5. KD dan Materi yang Mengandung Konten Uncertainty dan Data

\begin{tabular}{|c|c|}
\hline Kompetensi Dasar (KD) & Materi \\
\hline $\begin{array}{c}\text { Menentukan dan menganlisisis ukuran pemusatan dan penyebaran } \\
\text { data yang disajikan dalam bentuk tabel distribusi frekuensi dan } \\
\text { histogram }\end{array}$ & Statistika \\
\hline $\begin{array}{c}\text { Menyelesaikan masalah yang berkaitan dengan penyajian data hasil } \\
\text { pengkuruan dan pencacahan dalam tabel distribusi frekuensi dan } \\
\text { histogram }\end{array}$ & Statika \\
\hline
\end{tabular}

\section{Desain}

Pada tahap awal ini, peneliti mengembangkan soal matematika bermuatan HOTS setara PISA berkonteks Pancasila sebanyak 5 unit soal yang tediri dari 11 butir soal. Peneliti juga membuat kisikisi soal, kartu soal, dan kunci jawaban sebagai bahan pertimbangan bagi validator untuk memeriksa validasi soal matematika bermuatan HOTS setara PISA berkonteks Pancasila.

\section{Tahap prototyping}

Expert Review

Pada tahap ini soal divalidasi dari segi konten, konstruk, dan bahasa, dikonsultasikan dan diperiksa oleh Prof. Dr. M. Rusdi, M.Sc dan Dr. Kamid, M.Si. Selain itu, peneliti meminta pendapat dari dosen lain dan teman sejawat yang sudah berpengalaman dalam pendidikan matematika sebagai validator. Adapun saran dan komentar dari para pakar dan teman sejawat adalah sebagai berikut:

Tabel 6. Komentar/Saran dari validator serta keputusan revisi

\begin{tabular}{|c|c|}
\hline Nama Validator & Komentar \\
\hline Nizlel Huda & $\begin{array}{l}\text { 1. Semua soal sudah cukup bagus dan sesuai dengan standar PISA dan } \\
\text { bermuatan HOTS } \\
\text { 2. Kalimat yang digunakan juga sudah sesuai dengan kaidah bahasa } \\
\text { indonesia, mudah dipahami, dan tidak menimbulkan makna ganda } \\
\text { 3. Disiasati soalnya agar tidak terlalu panjang }\end{array}$ \\
\hline Agustarizal & $\begin{array}{l}\text { 1. } \\
\text { 2. } \\
\text { 3. }\end{array}$ \\
\hline Iqbal Fuady & $\begin{array}{l}\text { 1. Perbaiki beberapa kalimat pada soal } \\
\text { 2. Rinci dan perjelas kunci jawabannya }\end{array}$ \\
\hline
\end{tabular}

Berdasarkan komentar dan saran dari pakar dan teman sejawat tersebut, maka diambil langkah tindakan revisi sebagai berikut:

Tabel 7. Saran/komentar validator serta keputusan revisi

\begin{tabular}{|l|l|}
\hline \multicolumn{1}{|c|}{ Saran/Komentar } & \multicolumn{1}{c|}{ Keputusan Revisi } \\
\hline $\begin{array}{l}\text { Perbaiki penulisan kalimat } \\
\text { dan penggunaan tanda } \\
\text { baca pada setiap soal }\end{array}$ & $\begin{array}{l}\text { Penulisan kalimat dan penggunaan tanda baca pada soal } \\
\text { diperbaiki }\end{array}$ \\
\hline
\end{tabular}




\begin{tabular}{|l|l|}
\hline Disiasati soalnya agar & Kalimat "Taat beribadah sesuai agama merupakan bentuk \\
tidak terlalu panjang & pengamalan sila pertama. Ketika kita sudah memeluk suatu \\
agama tertentu, maka kita terikat untuk beriman dan bertakwa \\
kepada Tuhan. Salah satu aktivitas ibadah yang bisa dilakukan \\
oleh seorang muslim adalah membaca Al-Qur'an. Ayumi lahir \\
dan dibesarkan oleh sebuah keluarga pecinta Al-Qur'an. Abi dan \\
Uminya merupakan pengajar disebuah Taman Pendidikan Qur'an \\
(TPQ). Setiap ba'da shalat maghrib berjamaah, keluarga Ayumi \\
selalu mengisi waktu tersebut untuk membaca Al-Qur'an bersama \\
dan mempelajari maknanya sambil menunggu adzan isya'. Abi \\
Ayumi berkata, "Infiltrasi budaya masuk tanpa bisa kita screening \\
dengan baik, salah satunya yang bisa dilakukan adalah \\
memperkuat harapan anak-anak dengan menanamkan nilai-nilai \\
pancasila melalui kegiatan keagamaan." diganti menjadi \\
"Infiltrasi budaya masuk tanpa bisa discreening dengan baik. \\
Salah satu yang bisa dilakukan adalah menanamkan nilai-nilai \\
pancasila melalui kegiatan keagamaan. Bagi seorang muslim, \\
rutin membaca kitab Al-Qur'an sebagai pedoman hidupnya \\
merupakan bagian dari takwa kepada TYME"
\end{tabular}

One-to-one

Pada tahap one-to-one, prototype I juga diujicobakan kepada siswa. Dalam hal ini, soal diujicobakan kepada 3 orang siswa dengan kemampuan yang berbeda. Secara keseluruhan dari analisis terhadap lembar jawaban siswa, dapat terlihat bahwa siswa sudah dapat memahami soal dengan baik. Ini dapat diartikan bahwa prototype I tersebut sudah praktis untuk siswa. Walaupun ada beberapa soal yang belum dapat diselesaikan dengan benar oleh siswa. Ada beberapa kesalahan dalam melakukan perhitungan dan kesalahan dalam menginterpretasikan soal. Adapun saran dan komentar siswa diuraikan pada tabel 8 dibawah ini:

Tabel 8. Komentar dan Saran Siswa Pada Tahap One-to-One

\begin{tabular}{|c|c|c|c|}
\hline Komentar/Saran & S1 & S2 & S3 \\
\hline Soal terlalu panjang & $\mathrm{v}$ & $\mathrm{V}$ & $\mathrm{v}$ \\
\hline
\end{tabular}

Selain melalui tahap expert review dan one-to-one, prototype I juga divalidasi secara kuantitatif untuk mengetahui kevalidan dan realibilitas soal yang dikembangkan oleh peneliti. Analisis butir soal dilakukan dengan menggunakan perangkat Microsoft Excel. Uji validitas butir soal menggunakan korelasi product moment dari Karl Pearson. Validitas butir soal dapat dilihat pada tabel 9.

Tabel 9. Validitas butir soal unit 1

\begin{tabular}{|c|c|c|c|}
\hline Level Soal & r-tabel & r-hitung & keterangan \\
\hline 4 & 0,6021 & 0,6162 & valid \\
\hline
\end{tabular}


Perbandingan hasil validasi secara kualitatif dan kuantitatif untuk soal unit "Membaca Ayat Suci Al-Qur'an" dapat dilihat pada tabel 10.

Tabel 10. Perbandingan hasil validasi secara kualitatif dan kuantitatif

\begin{tabular}{|c|c|c|c|c|}
\hline \multirow[t]{3}{*}{ Unit } & \multicolumn{3}{|c|}{ Kualitatif } & \multirow[t]{3}{*}{ Kuantitatif } \\
\hline & \multirow[t]{2}{*}{ Expert Review } & \multicolumn{2}{|c|}{ One-to-one } & \\
\hline & & Teman Sejawat & Siswa & \\
\hline $\begin{array}{l}\text { Membaca ayat } \\
\text { suci al-qur'an }\end{array}$ & $\begin{array}{l}\text { a. Semua soal } \\
\text { sudah cukup } \\
\text { bagus dan } \\
\text { sesuai dengan } \\
\text { standar PISA } \\
\text { dan bermuatan } \\
\text { HOTS } \\
\text { b. Kalimat yang } \\
\text { digunakan juga } \\
\text { sudah sesuai } \\
\text { dengan kaidah } \\
\text { bahasa } \\
\text { indonesia, } \\
\text { mudah } \\
\text { dipahami, dan } \\
\text { tidak } \\
\text { menimbulkan } \\
\text { makna ganda } \\
\text { c. Disiasati } \\
\text { soalnya } \\
\text { agar } \\
\text { tidak } \\
\text { terlalu } \\
\text { panjang }\end{array}$ & $\begin{array}{l}\text { a. Soal sesuai } \\
\text { dengan } \\
\text { kemampuan } \\
\text { siswa } \\
\text { b. Soal sudah } \\
\text { sesuai dengan } \\
\text { KD } \\
\text { c. Perbaiki } \\
\text { kalimat sesuai } \\
\text { dengan EBI } \\
\text { d. Rinci dan } \\
\text { perjelas kunci } \\
\text { jawabannya }\end{array}$ & $\begin{array}{c}\text { Soal terlalu } \\
\text { panjang }\end{array}$ & Valid \\
\hline
\end{tabular}

Berdasarkan tabel 10, dapat dilihat perbandingan hasil validasi secara kualitatif dan kuantitatif untuk soal unit "Membaca ayat suci Al-Qur'an". Soal unit "Membaca ayat suci Al-Qur'an" dinyatakan valid secara kuantitatif. Hal ini sangat sesuai dengan komentar dan saran dari expert pada tahap expert review, dan sesuai pula dengan komentar teman sejawat serta siswa pada tahap one-toone. Soal unit "Membaca ayat suci Al-Qur'an" dapat dijawab oleh siswa namun siswa mengatakan bahwa soal terlalu panjang, sehingga peneliti merevisi dengan mempersingkat pengantar soal dan membuat pertanyaan agar lebih jelas. Berikut ini perbaikan soal yang dikembangkan oleh peneliti:

Tabel 11. Hasil revisi instrumen soal unit 1

\section{Pertanyaan 1: Membaca Ayat Suci Al-Qur'an}

Infiltrasi budaya masuk tanpa bisa discreening dengan baik. Salah satu yang bisa dilakukan adalah 
menanamkan nilai-nilai pancasila melalui kegiatan keagamaan. Bagi seorang muslim, rutin membaca kitab Al-Qur'an sebagai pedoman hidupnya merupakan bagian dari takwa kepada TYME. Ayumi lahir dan dibesarkan oleh sebuah keluarga pecinta Al-Qur'an. Setiap ba'da shalat maghrib berjamaah, keluarga Ayumi selalu mengisi waktu untuk membaca Al-Qur'an bersama dan mempelajari maknanya sambil menunggu adzan isya'. Selain membangun kebiasaan membaca AlQur'an di rumah, Ayumi juga diarahkan orangtuanya untuk belajar di TPQ sejak ia berusia 7 tahun. Pada tahun kelima ayumi belajar di TPQ tersebut, ada ketentuan baru untuk ujian kenaikan tingkat. Untuk itu, setiap santri dapat dinyatakan lulus ketika ia memperoleh nilai rata-rata di atas 85 , jika tidak, ia harus mengikuti ujian ulang hingga mendapat nilai rata-rata baru yang memenuhi syarat kelulusan. Nilai rata-rata baru tersebut merupakan nilai rata-rata dari nilai ujian yang terbaru ditambah nilai ujian sebelum-sebelumnya. Setiap bulan santri akan mendapatkan laporan bulanan yang didapat dari lima kali ujian. Jika pada ujian yang kedua Ayumi mendapat nilai 71, maka rataratanya adalah 83 . Sedangkan ujian ketiga ia mendapatkan nilai 86 , maka rata-ratanya adalah 84 . Dua kali ayumi absen karena sakit pada bulan itu saat pelaksanaan ujian. Keesokan harinya ia ikut ujian susulan. Namun, rata-rata nilai Ayumi tidak berubah dari rata-rata yang terakhir.

Manakah dari kesimpulan berikut yang dapat diambil dari informasi ini? Lingkari "Ya" atau “Tidak" untuk setiap kesimpulan.

\begin{tabular}{|c|c|}
\hline Kesimpulan & Apakah kesimpulan benar/salah? \\
\hline Ayumi tidak naik tingkat & Benar/Salah \\
\hline $\begin{array}{c}\text { Kedua nilai ujian susulan ayumi kemungkinan } \\
\text { adalah sama }\end{array}$ & Benar/Salah \\
\hline $\begin{array}{c}\text { Nilai susulan pertama mungkin adalah 80 dan } \\
\text { mungkin nilai susulan kedua adalah 87 }\end{array}$ & Benar/Salah \\
\hline $\begin{array}{c}\text { Jika ujian ke-4 ayumi mendapatkan nilai 83 dan } \\
\text { ujian ke-5 ayumi mendapatkan nilai 87, maka } \\
\text { besarnya penyebaran data nilai ayumi tersebut } \\
\text { adalah 6,8 }\end{array}$ & Benar/Salah \\
\hline Ujian pertama adalah nilai yang terendah & Benar/Salah \\
\hline
\end{tabular}

Berdasarkan hasil revisi draft soal sesuai saran dan komentar pada tahap expert review, one to one, dan validasi secara kuantitatif, dihasilkan prototype II yang diujicobakan kepada siswa pada tahap small group.

\section{Small Group}

Soal-soal yang telah direvisi berdasarkan expert review dan one-to-one dinamakan dengan prototype II. Soal-soal tersebut diujicobakan pada tahap small group yang terdiri dari 6 orang siswa SMA N 12 Kota Jambi. Dalam pelaksanaan small group, peneliti juga mengamati siswa ketika 
mengerjakan soal-soal yang diberikan. Berbeda dengan uji coba one-to-one, pada tahap uji coba small group intensitas siswa bertanya tentang maksud soal atau kalimat soal sudah berkurang. Pada tahap small group, prototype II diujikan kepada 6 siswa. Selama proses pengerjaan soal, peneliti mencatat hal-hal yang menjadi pertanyaan siswa mengenai soal yang sedang dikerjakan dan peneliti juga mewawancarai siswa untuk mengetahui respon, komentar, saran, serta untuk mengetahui kesulitan apa saja yang siswa alami. Berikut ini salah satu jawaban siswa pada tahap small group.

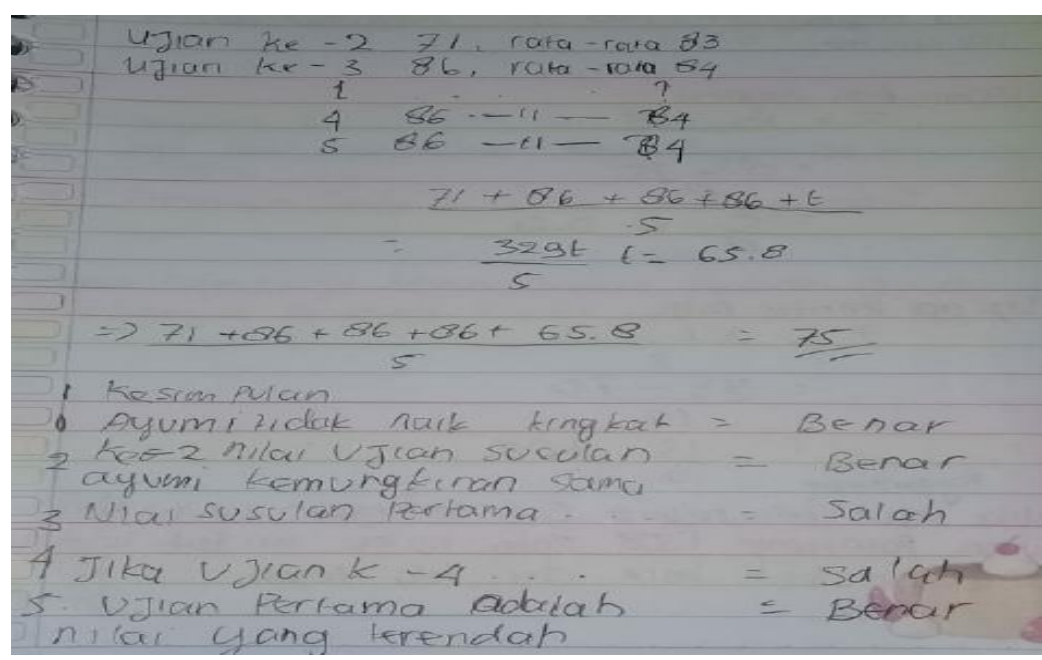

Gambar 1. Cuplikan Jawaban Siswa Pada Tahap Small Group

Pada gambar 1 terlihat bahwa siswa menyatakan soal yang diberikan oleh peneliti kurang tepat. Saat diwawancarai, siswa menyatakan bahwa sudah mengerti maksud soal namun soal tersebut panjang dan fokus terganggu. Berdasarkan komentar tersebut, soal tetap dipertahankan tanpa revisi oleh peneliti karena peneliti mendesain soal tersebut agar siswa terlatih dengan soal bermuatan HOTS setara PISA dan mampu mengasah kemampuan literasinya. Draft soal yang dihasilkan dari tahap small group disebut prototype III, yang kemudian diujikan pada tahap field test.

\section{Field Test}

Pada tahap field test, prototype III diujicobakan pada subjek penelitian yaitu siswa SMA N 12 Kota Jambi sebanyak 30 siswa. Saat siswa mengerjakan soal, peneliti bertanya kepada beberapa orang siswa untuk mengetahui cara berpikir siswa tersebut dalam mengerjakan soal yang diberikan. Kemudian, peneliti menganalisis hasil jawaban siswa untuk mengetahui kemampuan literasi siswa saat mengerjakan soal yang dikembangkan oleh peneliti. Berikut jawaban siswa pada tahap field test.

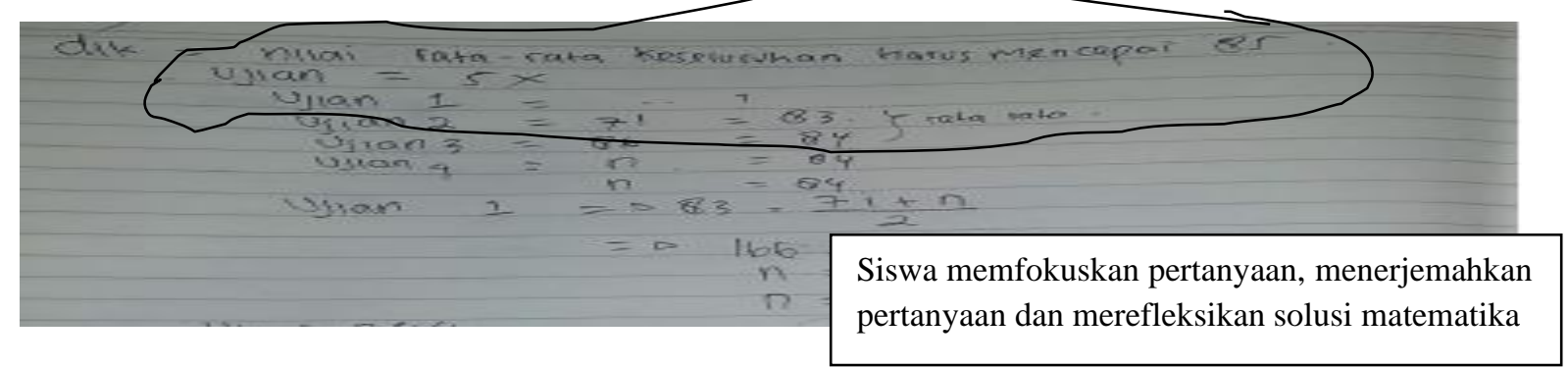

Gambar 2. Jawaban HF 
Pada gambar 3 terlihat bahwa HF memperoleh full credit dengan proses formulate. Adapun kemampuan literasi matematis yang terlihat dari pengerjaan soal tersebut yaitu kemampuan komunikasi, yaitu siswa HF dapat menerjemahkan pertanyaan dan menuliskannya dengan lengkap dan benar. Kemampuan matematisasi dengan menggunakan pemahaman konteks untuk menyelesaikan masalah matematika dapat dilakuakan siswa HF dengan tepat. Selanjutnya kemampuan representasi dengan indikator menggunakan dan menghubungkan berbagai macam representasi dalam pemecahan masalah dapat dilakukan siswa HF dengan lengkap dan benar. Kemampuan penalaran dan argumen dengan indikator menghubungkan informasi yang telah didapat sebelumnya untuk menemukan solusi siswa HF dapat menggunakan penalaran dengan benar. Kemampuan menggunakan bahasa dan operasi simbol, formal, dan teknis dengan indikator menggunakan bentuk formal berdasarkan definisi dan aturan matematika siswa HF dapat menggunakan dengan lengkap. Adapun persentase munculnya kemampuan literasi matematis untuk 30 siswa pada soal unit 1 adalah sebagai berikut:

Tabel 13. Persentase kemampuan literasi matematis soal unit 1

\begin{tabular}{|c|c|c|}
\hline Kemampuan & Banyak Siswa & Persentase \\
\hline Komunikasi & 15 & $48,3 \%$ \\
\hline Matematisasi & 6 & $19,4 \%$ \\
\hline Representasi & 5 & $16,1 \%$ \\
\hline Penalaran dan argument & 4 & $12,9 \%$ \\
\hline $\begin{array}{c}\text { Menggunakan bahasa dan operasi simbol, formal, dan } \\
\text { teknis dengan indikator menggunakan bentuk formal }\end{array}$ & 3 & $9,66 \%$ \\
\hline
\end{tabular}

Berdasarkan jawaban siswa pada tahap field test dan disesuaikan dengan indikator kemampuan literasi matematis, kemampuan literasi yang dominan adalah kemampuan komunikasi. Salah satu poin framework PISA (OECD, 2018) bahwa literasi matematis membantu seseorang untuk mengenali peranan matematika dalam menyelesaikan masalah di kehidupan sehari-hari. Disamping itu, dalam literasi matematika, siswa juga menggunakan visual, representasi simbolis, dan verbal. Strategi yang digunakan siswa dalam memecahkan masalah matematika yang dijumpai merupakan representasi ganda, yang berarti dalam setiap masalah, siswa dapat menggunakan lebih banyak dari satu bentuk representasi. Sesuai dengan yang dikatakan oleh (Lestariningsih, 2020), guru bisa mengetahui pola pikir dan ide siswa dari representasi yang dibuat oleh siswa. Dari setiap pertanyaan pada soal unit 1 menunjukkan bahwa kegiatan keagamaan memiliki keterkaitan dengan matematika yaitu siswa harus melewati jenjang-jenjang prestasi tertentu yang perhitungannya menggunakan perhitungan matematika. Hal ini didukung oleh penelitian (Himawan, 2020), bahwa mengintegrasikan nilai pancasila dapat meningkatkan keterampilan pemecahan masalah siswa.

Selanjutnya, soal dalam penelitian ini merujuk pada manfaat atau efek apa saja yang dapat diberikan oleh soal yang dikembangkan kepada subjek peneliti dalam hal ini siswa SMA N 12 Kota Jambi. Efek yang dilihat dari penelitian ini keseriusan siswa dalam menyelesaikan soal, tanggapan atau komentar siswa terhadap soal matematika bermuatan HOTS setara PISA konteks Pancasila, 
potensi kemampuan literasi matematis yang mungkin dapat dimunculkan siswa selama proses penyelesaian setiap butir soal. Dengan adanya latihan soal matematika bermuatan HOTS setara PISA dalam pembelajaran dapat memunculkan potensi kemampuan literasi siswa.

\section{KESIMPULAN}

Berdasarkan hasil dan pembahasan, maka dapat disimpulkan sebagai berikut: 1) Penelitian ini telah menghasilkan soal matematika bermuatan HOTS setara PISA yang valid dan praktis serta memiliki efek potensial. Kevalidan soal ditunjukkan dari hasil penilaian validator pada tahap expert review dan one-to-one yang menyatakan bahwa soal telah baik dari segi konten, konstruk, dan bahasa. Hal ini juga terlihat pada small group bahwa siswa dapat menggunakan perangkat soal dengan baik. Soal juga telah diujikan pada tahap field test untuk mengetahui kemampuan literasi matematis siswa. 2) Dari hasil analisis jawaban siswa, kemampuan literasi matematis yang dominan adalah kemampuan komunikasi.

\section{UCAPAN TERIMA KASIH}

Peneliti mengucapkan syukur kepada Allah SWT karena telah diberikan kelancaran menyelesaikan artikel ini. Kemudian berterima kasih juga kepada orang tua, Bapak Ir. Zul Fahri Gani, MP dan Ibu Amnah, S.Pd serta suami Rinaldy Putra Utama, S.Pd yang telah memberikan dukungannya selalu. Terimakasih kepada dosen pembimbing Bapak Prof. Dr. M. Rusdi, M.Sc dan Bapak Dr. Kamid, M.Si yang telah membimbing dan mengarahkan dalam menyelesaikan artikel ini serta terimakasih kepada saudara dan para sahabat yang selalu memberikan semangat.

\section{REFERENSI}

Addi M.Idhom. (2020). Nadiem Ungkap 5 Strategi untuk Kerek Skor PISA Indonesia. https://tirto.id/nadiem-ungkap-5-strategi-untuk-kerek-skor-pisa-indonesia-eKF7

De Lange, J. (2004). Mathematical Literacy for Living from OECD-PISA Perspective. Paris:OECDPISA

Dewi, N. R. (2020). The effectiveness of multicultural education through traditional games-based inquiry toward improving student scientific attitude. In Journal of Physics: Conference Series (Vol. 1567, Issue 4). https://doi.org/10.1088/1742-6596/1567/4/042051

Hayat, B. dan Yusuf, S. 2010. Mutu Pendidikan. Jakarta: Bumi Aksara

Heuvel-Panhuizen, M. Van Den. (1996). Assessment and realistic mathematics education. In Assessment.

Himawan, N. (2020). Improving students' problem-solving skills through quick on the draw model assisted by the optical learning book integrated the Pancasila. In Journal of Physics: Conference Series (Vol. 1440, Issue 1). https://doi.org/10.1088/1742-6596/1440/1/012031

JULAIKA, J., \& MARIANA, N. (2018). EKSPLORASI NILAI-NILAI PANCASILA UNTUK MENTRANSFORMASI KONTEKS DALAM PEMBELAJARAN MATEMATIKA DI SEKOLAH DASAR. Jurnal Penelitian Pendidikan Guru Sekolah Dasar. 
Jurnaidi, J., \& Zulkardi, Z. (2014). PENGEMBANGAN SOAL MODEL PISA PADA KONTEN CHANGE AND RELATIONSHIP UNTUK MENGETAHUI KEMAMPUAN PENALARAN MATEMATIS SISWA SEKOLAH MENENGAH PERTAMA. Jurnal Pendidikan Matematika. https://doi.org/10.22342/jpm.8.1.1860.25-42

Kemendikbud. (2017). Modul Penyusunan Higher Order Thingking Skill (HOTS). Direktorat Pembinaan Sma Direktorat Jenderal Pendidikan Dasar Dan Menengah Departemen Pendidikan Dan Kebudayaan 2017.

Kemendikbud, T. G., Jenderal, J., Senayan, S., Pusat, J., \& Ristekdikti. (2018). Mengapa literasi sains penting? $\bullet$ Gerakan Literasi Nasional.

Krathwohl. 1997. Methods of Educational and Social Science Research, Second Edition. New York: Longman, Inc

Kurniati, D., Harimukti, R., \& Jamil, N. A. (2016). Kemampuan berpikir tingkat tinggi siswa SMP di Kabupaten Jember dalam menyelesaikan soal berstandar PISA. Jurnal Penelitian Dan Evaluasi Pendidikan. https://doi.org/10.21831/pep.v20i2.8058

Lestariningsih, L. (2020). Development of mathematical literacy problems to empower students' representation. In Journal of Physics: Conference Series (Vol. 1464, Issue 1). https://doi.org/10.1088/1742-6596/1464/1/012018

NCTM. 2000. Principles and Standards for School Matematics. Reson, VA: Author

OECD. (2019). PISA 2018 Assessment and Analytical Framework. OECD. https://doi.org/10.1787/b25efab8-en.

OECD. 2010. Draft PISA 2012 Assessment Framework. Tersedia: http://www.oecd.org.dataoecd/61/15/46241909.pdf.

Panjaitan, M. J. S. (2020). Concept of state based on Pancasila, the 1945 constitution in criminal radicalism. Utopia y Praxis Latinoamericana, 25, 98-110. https://doi.org/10.5281/zenodo.3809012

Pengembangan Soal Penalaran Tipe TIMSS Menggunakan Konteks Budaya Lampung. (2016). Jurnal Didaktik Matematika. https://doi.org/10.24815/jdm.v3i1.4300

Shiel, Gerry dk. 2007. PISA Mathematics: A Teacher's Guide. Stationery Office.

Stacey, K., \& Turner, R. (2015). Assessing mathematical literacy: The PISA experience. In Assessing Mathematical Literacy: The PISA Experience. https://doi.org/10.1007/978-3-319-10121-7

Sutopo, S. (2020). Pancasila ethics and culture-based education model for vocational high school. In Journal of Physics: Conference Series (Vol. 1446, Issue 1). https://doi.org/10.1088/1742$6596 / 1446 / 1 / 012055$

Tessmer, M. (1993). Planning and conducting formative evaluations: Improving the quality of education and training. In Planning and Conducting Formative Evaluations.

Van den Akker, J. (1999). Principles and Methods of Development Research. In Design Approaches and Tools in Education and Training. https://doi.org/10.1007/978-94-011-4255-7_1

Wardani, S., \& Rumiati. (2011). INSTRUMEN PENILAIAN HASIL BELAJAR MATEMATIKA SMP : Belajar dari PISA dan TIMSS. Yogyakarta: PPPPTK Matematika.

Widiatsih, A. (2020). The development of mathematical problem based on Higher Order Thinking Skill (HOTS) on comparative material by implementing PBL and its effect on the teacher's 
creative thinking skill. In Journal of Physics: Conference Series (Vol. 1538, Issue 1). https://doi.org/10.1088/1742-6596/1538/1/012110 